\title{
Arah dan Trend Penelitian Pendidikan Matematika di Jurnal Riset Pendidikan Matematika (JRPM)
}

Directions and Trends of Mathematical Education Research In Jurnal Riset Pendidikan Matematika (JRPM)

\author{
Renita Br PeranginAngin ${ }^{1}$, Simon Panjaitan1, Agusmanto Hutauruk ${ }^{1}$, Efron \\ Manik $^{1}$, Hardi Tambunan ${ }^{1}$ \\ 1Pascasarjana Universitas HKBP Nommensen Medan
}

*Email Korespondensi: peranginangin.renita@gmail.com

\begin{tabular}{lll}
\hline \hline Info Artikel & \\
\hline Diterima & $:$ & $23 \mathrm{Jan} 21$ \\
Direvisi & $:$ & $8 \mathrm{Feb} 21$ \\
Diterbitkan & $:$ & $28 \mathrm{Feb} 21$ \\
& & \\
& & \\
\hline
\end{tabular}

Kata Kunci:

Trend, Topik, Subjek Penelitian, JRPM

Cara merujuk artikel ini:

Peranginangin, R. Br., dkk. (2021). Arah dan Trend Penelitian Pendidikan Matematika di Indonesia. Vygotsky: Jurnal Pendidikan Matematika dan Matematika, 3 (1), 49-62. Diunduh dari https://jurnalpendidikan. unisla.ac.id/index.php/ $\mathrm{VoJ} /$ article/view/340

\begin{abstract}
This literature study examines the direction and trends of mathematics education research in line with new trends and findings in mathematics education. Past mathematics education research topics were dominated by NCTM with a focus on primary education students as research subjects. Currently the research topic of mathematics education examines the high-level thinking process of students with an evenly distributed subject. Future mathematics education research will also examine higher-order thinking skills which place more emphasis on $4 C$ abilities (creativity, crictical thinking, communication, collaboration). The existence of the Covid-19 pandemic and also the implementation of the independent campus curriculum and independent learning will have an impact on mathematics education.

\begin{tabular}{l}
\hline Abstrak \\
\hline Studi literatur ini mengkaji arah dan trend \\
penelitian pendidikan matematika sejalan dengan \\
trend dan temuan baru dalam pendidikan \\
matematika. Topik penelitian pendidikan \\
matematika masa lalu didominasi oleh NCTM \\
dengan fokus ke siswa pendidikan dasar sebagai \\
subjek penelitian. Saat ini topik penelitian \\
pendidikan matematika mengkaji ke arah proses \\
berpikir tingkat tinggi siswa dengan subjek yang \\
merata. Penelitian pendidikan matematika ke \\
depan juga akan mengkaji kemampuan berpikir \\
tingkat tinggi yang lebih ditekankan pada \\
kemampuan 4C (creativity, crictical thinking, \\
communication, collaboration). Adanya pandemi \\
covid-19 dan juga penerapan kurikulum kampus \\
merdeka dan merdeka belajar akan berdampak \\
terhadap pendidikan matematika.
\end{tabular}
\end{abstract}

Copyright ( 2021 Vygotsky: Jurnal Pendidikan Matematika dan Matematika. All right reserved 


\section{PENDAHULUAN}

Penelitian pendidikan matematika sangat dibutuhkan untuk dapat membantu memecahkan masalah dan problematika pembelajaran matematika yang ada serta memberikan upaya dan terobosan baru dalam pengembangkan ilmu pendidikan dan pembelajaran matematika. Dalam pelaksanaan kegiatan penelitian pendidikan matematika, paper ini akan memaparkan profil penelitian pendidikan matematika di Indonesia yang sudah berkembang dan sudah terlaksana pada masa lalu dan terkini serta untuk mengetahui trend dan isu-isu yang telah dikajinya, khususnya dalam kurun waktu masa lalu (tahun 2017- 2018), trend yang sedang berkembang saat ini tahun 2019 - tahun 2020 (2 tahun terakhir) dan juga gambaran trend penelitian pendidikan matematika masa depan. Metode yang digunakan adalah studi literatur. Tujuan penelitian ini adalah untuk melihat gambaran penelitian masa lalu dan sekarang serta untuk mengetahui arah dan kecenderungan penelitian pendidikan matematika masa depan. Diharapkan artikel ini dapat menjadi referensi bagi para peneliti yang akan melaksanakan penelitian di bidang pendidikan matematika, untuk mendapatkan gambaran tentang arah dan trend penelitian.

\section{BAHASAN UTAMA}

Penelitian pendidikan matematika saat ini sangat berkembang cepat, hal ini dapat terlihat dari banyaknya organisasi penelitian pendidikan matematika seperti European Mathematical Society (EMS), International Mathematical Union (IMU), International Society for Mathematical Sciences, International Group for Psychological Mathematics Education (IGPME), European Researchers of Mathematics Education (ERME), dan sebagainya. Selanjutnya, hasil penelitian pendidikan matematika juga dideseminasikan melalui seminar dan konferensi pendidikan matematika, seperti Conference of the European Research in Mathematics Education (CERME), dan di Indonesia ada Konferensi Nasional Pendidikan Matematika (KNPM). Selain melalui kegiatan seminar dan konferensi, deseminasi hasil penelitian banyak dilakukan melalui publikasi jurnal, baik dalam bentuk cetak maupun elektronik (online), seperti Journal for Research in Mathematics Education (JRME), Journal of Mathematics Teacher Education (JMTE), dan di Indonesia ada IndoMS Journal of Mathematics Education (IndoMS JME), Jurnal on Mathematics Education (JME) yang dikelola oleh Universitas Sriwijaya, dan Jurnal Riset Pendidikan Matematika (JRPM) yang dikelola oleh Universitas Negeri Yogyakarta.

Pada studi literatur, peneliti memilih JRPM sebagai salah satu jurnal yang telah terakreditasi Dikti dan DOAJ untuk ditelaah. Studi literatur ini menggambarkan, mengidentifikasi, dan menjelaskan profil penelitian pendidikan matematika pada JRPM, dengan 3 acuan pembahasan,yakni: (1) Topik/ isu-isu dan permasalahan yang diteliti, (2) siapa yang dijadikan sebagai subyek penelitian, (3) pendekatan dan metode apa yang digunakan dalam penelitian tersebut. 


\section{Trend Penelitian Pendidikan Matematika Masa Lalu (Tahun 2017-2018)}

Pada penelitian pendidikan matematika masa lalu (tahun 2017-2018) di Jurnal Riset Pendidikan Matematika (JRPM) Univ. Neg. Yogyakarta dapat dilihat pada Tabel 1. Tabel 1 memberikan gambaran topik/isu umum permasalahan yang dikaji oleh para peneliti dari tahun 2017 sampai dengan tahun 2018. Beberapa peneliti seperti: Fatmasuci (2017); Habsah (2017); Samo (2017); Utami \& Wutsqa (2017), Susanti \& Wutsqa (2020); Purwasih \& Bernad (2018); Johar \& Lubis (2018), dll mengkaji tentang kemampuan matematis oleh National Council of Teacher Mathematic (NCTM). Ada 5 pengelompokan kemampuan matematis menurut NCTM yaitu kemampuan pemecahan masalah, penalaran dan bukti matematis, komunikasi matematis, koneksi matematis dan representasi matematis (Martin, 2000). Topik kajian kemampuan matematis NCTM ini menjadi topik penelitian yang paling banyak dikaji oleh para peneliti.

Penelitian yang dilakukan oleh Fatmasuci (2017); Habsah (2017); Satrianawati (2017); Latifah \& Widjajanti (2017); Salim \& Maryanti (2017)memilih topik desain atau mengembangkan model/teori/kurikulum. Sementara itu topik mengenai kemampuan tingkat tinggi siswa (HOTS) telah dikaji oleh Nursyahidah \& Albab (2017); Jailani et al., (2017); Sariningsih \& Herdiman (2017); (Noer (2018); Hardiyanto \& Santoso (2018).

Beberapa peneliti seperti Sari \& Wijaya (2017); Kartianom \& Ndayizeye (2017); Atsnan et al., (2018) telah mengkaji mengenai PISA dan literasi matematika. Sementara itu penelitian yang dilaksanakan oleh Wibowo (2017); Astutik (2017); Narendrati (2017); Satriawan (2017); Utami \& Wutsqa (2017); Purnomo et al., (2018) mengkaji topik mengenai afektif siswa seperti minat, motivasi, selfefficacy. Topik penelitian mengenai afektif didominasi oleh minat belajar.

Tabel 1. Topik Kajian Penelitian Pendidikan Matematika Masa Lalu

\begin{tabular}{clc}
\hline No & \multicolumn{1}{c}{ Topik Kajian } & Jumlah \\
\hline 1 & Masalah Kontekstual /RME & 3 \\
2 & Desain Model/Perangkat/Kurikulum & 7 \\
3 & Kemampuan Matematis (NCTM) & 19 \\
4 & Literasi Matematika & 3 \\
5 & Media/Teknologi & 3 \\
6 & HOTS & 11 \\
7 & Afektif & 10 \\
\hline
\end{tabular}

Dari Tabel 1 dapat dilihat bahwa penelitian pendidikan matematika masa lalu didominasi oleh topik kemampuan matematis NCTM. Hal ini diakibatkan penelitian pendidikan matematika masa lalu fokus terhadap kemampuan kognitif berpikir siswa, masih sedikit yang meneliti tentang 
afektif dan psikomotorik serta prosese berpikir matematika siswa.

Dilihat dari subjek penelitian, penelitian pendidikan matematika masa lalu dominan mengambil subjek penelitian pada siswa SMP sederajat. Tabel 2 menunjukkan rekapitulasi subjek penelitian pendidikan matematika masa lalu. Dapat dikatakan subjek penelitian pendidikan matematika masa lalu dominan terfokus pada siswa saja. Belum banyak penelitian yang subjek penelitiannya ditujukan kepada guru sebagai pendidik, dan hanya sebagaian kecil peneliti yang mengambil subjek penelitian pada pendidikan tinggi.

Tabel 2. Subjek Penelitian Pendidikan Matematika Masa Lalu

\begin{tabular}{clc}
\hline No & \multicolumn{1}{c}{ Subjek Penelitian } & Jumlah \\
\hline 1 & Siswa Sekolah Dasar (SD) Sederajat & 9 \\
2 & Siswa Sekolah Menengah Pertama (SMP) Sederajat & 26 \\
3 & Siswa Sekolah Menengah Atas (SMA) Sederajat & 13 \\
4 & Mahasiswa & 10 \\
5 & Guru & 0 \\
\hline
\end{tabular}

Metode penelitian pendidikan matematika masa lalu lebih banyak menggunakan pendekatan kuantitatif. Pendekatan kuantitatif ini sejalan dengan banyaknya topik penelitian mengenai kemampuan matematis. . Jenis pendekatan kualitatif umumnya digunakan pada penelitian yang bersifat analisis seperti penelitian Nursyahidah \& Albab (2017); Novita et al. (2018); Wasida \& Hartono (2018), Setiawan et al. (2018) dll.

Tabel 3. Metode Pendekatan Penelitian Pendidikan Matematika Masa Lalu

\begin{tabular}{clc}
\hline No & \multicolumn{1}{c}{ Jenis Pendekatan } & Jumlah \\
\hline 1 & Pendekatan Kuantitatif & 37 \\
2 & Pendekatan Kualitatif & 9 \\
3 & Mixed Method & 1 \\
\hline
\end{tabular}

Trend Penelitian Pendidikan Matematika Saat Ini (Tahun 2019-2020)

Pada penelitian pendidikan matematika sekarang ( 2 tahun terakhir) di Jurnal Riset Pendidikan Matematika (JRPM) Univ. Neg. Yogyakarta dapat dilihat pada Tabel 4 . Tabel 4 memberikan gambaran topik/isu umum permasalahan yang dikaji oleh para peneliti dari tahun 2019 sampai dengan tahun 2020. Beberapa peneliti seperti Farib et al. (2019), Agus (2019); Miatun \& Nurafni (2019); Setiana \& Purwoko (2020) mengkaji tentang kemampuan tingkat tinggi siswa (HOTS). Kemampuan matematis oleh NCTM dikaji oleh Kurniyawati et al., (2019); Hadiat \& Karyati (2019); Susanti \& Wutsqa (2020); Arivina \& Jailani (2020).

Topik mengenai desain model/kurikulum dikaji oleh Lutfi (2019); Nugroho (2019); Hariyanti \& Wutsqa (2020); Arifin et al. (2020); Arifin et 
al., (2020), sementara topik/isu mengenai Literasi Matematika atau PISA/TIMSS dikaji oleh Hamidy \& Jailani (2019); Hariyanti \& Wutsqa (2020).

Topik mengenai media pembelajaran/teknologi dalam pembelajaran dikaji oleh Nurdin et al., (2019); Arifin et al. (2020); juga Safitri et al., (2020). Sementara topik mengenai pandemi covid-19 dikaji oleh Wahyuningrum \& Latifah (2020).

Tabel 4. Topik Kajian Penelitian Pendidikan Matematika Saat Ini

\begin{tabular}{clc}
\hline No & \multicolumn{1}{c}{ Topik Kajian } & Jumlah \\
\hline 1 & Kemampuan Matematis (NCTM) & 10 \\
2 & Kemampuan Kognitif & 3 \\
3 & Desain Model/Kurikulum & 7 \\
4 & HOTS & 13 \\
5 & Media/Teknologi & 7 \\
6 & Literasi Matematika & 4 \\
7 & Pandemi Covid-19 & 1 \\
\hline
\end{tabular}

Dari Tabel 4 dapat dilihat bahwa penelitian pendidikan matematika dua tahun terakhir didominasi oleh topik HOTS. Dilihat dari subjek penelitian, penelitian pendidikan matematika sekarang cenderung berimbang dalam memilih subjek penelitian pada tingkat pendidikan dasar dan menengah. Tabel 5 menunjukkan rekapitulasi subjek penelitian pendidikan matematika saat ini. Menariknya pada penelitian pendidikan matematika 2 tahun terakhir ini adalah pemilihan guru sebagai subjek penelitian pendidikan matematika. Hal ini menandakan bahwa dapat dikatakan mutu pendidikan di Indonesia juga dipengaruhi oleh kualitas dan profesionalisme guru. Hal ini sejalan dengan Conway \& Sloane (2005); UNESCO (2014) by 2030, semua pemerintah memastikan bahwa semua peserta didik diajar oleh guru yang berkualitas, terlatih secara profesional, termotivasi dan didukung dengan baik".

Tabel 5. Subjek Penelitian Pendidikan Matematika Sekarang

\begin{tabular}{clc}
\hline No & \multicolumn{1}{c}{ Subjek Penelitian } & Jumlah \\
\hline 1 & Siswa Sekolah Dasar (SD) Sederajat & 8 \\
2 & Siswa Sekolah Menengah Pertama (SMP) Sederajat & 13 \\
3 & Siswa Sekolah Menengah Atas (SMA) Sederajat & 13 \\
4 & Mahasiswa & 3 \\
5 & Guru & 3 \\
\hline
\end{tabular}

Metode penelitian pada penelitian pendidikan matematika sekarang masih tetap lebih banyak menggunakan pendekatan kuantitatif. Disamping metode penelitian kuantitatif dan kualitatif, studi literatur juga sudah lebih sering digunakan dalam penelitian sekarang. Jenis 
pendekatan kuantitaif umumnya digunakan pada penelitian eksperimen dengan menerapkan metode baru atau teknologi baru dalam pembelajaran.

Tabel 6. Metode Pendekatan Penelitian Pendidikan Matematika Sekarang

\begin{tabular}{clc}
\hline No & \multicolumn{1}{c}{ Jenis Pendekatan } & Jumlah \\
\hline 1 & Pendekatan Kuantitatif & 29 \\
2 & Pendekatan Kualitatif & 7 \\
3 & Mixed Method & 6 \\
4 & Studi Literatur & 4 \\
\hline
\end{tabular}

\section{Trend Penelitian Pendidikan Matematika Masa Depan}

Trend Penelitian pendidikan matematika pada masa depan akan dipengaruhi oleh perkembangan ilmu pengetahuan dan teknologi yang pesat yang akan mendorong pembaharuan dalam pembelajaran serta adanya pandemi Covid-19 juga akan berdampak pada metode dan pendekatan pembelajaran yang digunakan. Pada era informasi saat ini siswa harus berkompetisi pada masyarakat global sehingga siswa dituntut mempunyai kreativitas (creativity), kemampuan berpikir kritis (critical thinking), berkomunikasi (communication), dan berkolaborasi (collaboration), yang lebih dikenal dengan akronim 'Four Cs'(Association (2012); Murtiyasa (2016)). Sekolah melalui pendidik harus mampu melengkapi keterampilan 4C guna menyiapkan siswanya sebagai insan yang tanggap serta mampu menghadapi persaingan global. Dalam hal model atau proses pembelajaran ke depan akan didominasi oleh pembelajaran blanded learning dengan memanfaatkan teknologi untuk pembelajaran jarak jauh.

Program menteri pendidikan melalui kampus merdeka dan merdeka belajar juga akan mempengaruhi arah dan trend penelitian pendidikan matematika masa depan. Keterampilan dan soft skill siswa pada program kampus merdeka dan merdeka belajar akan menjadi ranah baru bagi peneliti pendidikan matematika masa depan. Dan tentunya para peneliti masa depan akan lebih bersanding antar lembaga atau kampus dalam melaksanakan penelitian.

Subjek Penelitian pada penelitian pendidikan matematika pada masa depan juga akan didominasi oleh siswa di tingkat pendidikan dasar. Hal ini sesuai dengan pemikiran bahwa waktu siswa berada pada tingkat dasarlah saat yang paling tepat untuk mengembangkan pemahaman dan pemikirannya tentang matematika. Literasi matematika dan literasi numerasi masih menjadi tantangan utama pada pendidikan matematika dasar. Literasi matematika untuk semua anak muda tidak hanya tujuan, tetapi juga tujuan prioritas dasar matematika yang diajarkan selama pendidikan dasar(UNESCO, 2014). Hal ini dikarenakan saat ini perolehan pencapaian Indonesia di penilaian PISA dan TIMSS masih jauh dari yang diharapkan, serta program pemerintah melalui kementerian pendidikan dalam hal peningkatan literasi numerasi siswa. Pelaksanaan program atau 
kurikulum kampus merdeka juga akan mempengaruhi subjek penelitian pendidikan ke depan. Subjek penelitian ke mahasiswa akan berimbang dengan subjek penelitian ke sekolah-sekolah.

Sementara itu Stephan et al., (2015) menyampaikan tiga tantangan terbesar dalam pendidikan matematika, yaitu kerja matematika (doing mathematics), peran matematika di masyarakat (the role of mathematics in society), dan kesetaraan dalam pendidikan matematika (Equity In Mathematics Education). Murtiyasa (2016) mengatakan kerja matematika ialah tentang pemecahan masalah, penalaran, rasa ingin tahu, kegembiraan, dan bukan sekedar mengikuti prosedur untuk mendapatkan jawaban. Peran matematika dimasyarakat dimaksudkan bahwa perlunya melihat matematika merupakan aktivitas manusia dalam keseharian, sedangkan kesetaraan dalam pendidikan matematika dimaksudkan semua target-target dalam pendidikan matematika harus dapat dicapai oleh semua kelompok, tidak boleh ada yang tertinggal. Hal ini sejalan dengan deklarasi Incheon yang menyatakan bahwa inklusi dan kesetaraan dalam pendekatan Pendidikan adalah landasan dari agenda pendidikan transformatif (UNESCO, 2015).

\section{SIMPULAN}

Trend penelitian pendidikan matematika berkembang sejalan dengan perkembangan ilmu pengetahuan dan teknologi serta situasi yang mempengaruhi masyarakat dan dunia. Arah penelitian pendidikan matematika sejalan dengan temuan-temuan baru di dalam pendidikan matematika. Penelitian pendidikan matematika pada masa lalu yang didominasi oleh desain/model kurikulum termasuk teori pembelajaran berubah ke arah teknologi/media pembelajaran matematika dan penelitian mengenai proses berpikir tingkat tinggi siswa. Penelitian pendidikan matematika pada masa yang akan datang juga akan mengkaji mengenai kemampuan berpikir tingkat tinggi dan akan lebih ditekankan kepada kemampuan 4-C (four Cs) hal ini diakibatkan tuntutan kebutuhan globalisasi zaman dewasa sekarang terhadap kemampuan siswa.

Penerapan kurikulum kampus merdeka dan merdeka belajar serta pengenalan istilah literasi numerasi akan berdampak juga pada penelitian pendidikan matematika ke depan. Topik penelitian ke depan akan banyak mengkaji tentang proses dan pelaksanaan kurikulum kampus merdeka dan merdeka belajar serta akan mempengaruhi subjek penelitian.

Adanya pandemi covid-19 juga akan mempengaruhi penelitian pendidikan matematika ke depan. Penelitian mengenai model pembelajaran yang menggunakan sistem pembelajaran jarak jauh atau juga blended learning akan lebih banyak digunakan dibanding sitem pembelajaran tatap muka seperti biasa.

Subjek penelitian pendidikan matematika pada masa sekarang lebih berkembang dibandingkan dengan penelitian pendidikan matematika pada masa lalu. Dimana pada penelitian pendidikan matematika sekarang, guru menjadi subjek penelitian yang baru dan hal ini juga 
nantinya akan sejalan dengan trend penelitian pendidikan matematika pada masa yang akan datang.

Jenis pendekatan penelitian pendidikan matematika juga akan berkembang setiap saat. Pendidikan metematika pada masa lalu masih banyak menggunakan jenis pendekatan kualitatif, sedangkan penelitian sekarang didominasi oleh jenis pendekatan kuantitatif dan penelitian pendidikan matematika pada masa yang akan datang memberikan peluang yang lebih besar akan menggunakan campuran dari jenis penelitian kualitatif dan kuantitatif (mixed method) serta studi literatur.

\section{DAFTAR RUJUKAN}

Agus, I. (2019). Efektivitas guided discovery menggunakan pendekatan kontekstual ditinjau dari kemampuan berpikir kritis, prestasi, dan self-efficacy. Jurnal Riset Pendidikan Matematika, 6(2), 120-132. Jurnal Riset Pendidikan Matematika, 6(2), 120-132. Diunduh dari https://journal.uny.ac.id/index.php/jrpm/article/view/14517/13403

Arifin, A. M., Pujiastuti, H., \& Sudiana, R. (2020). Pengembangan media pembelajaran STEM dengan augmented reality untuk meningkatkan kemampuan spasial matematis siswa. Jurnal Riset Pendidikan Matematika, 7(1), 59-73. Diunduh dari https://journal.uny.ac.id/index.php/jrpm/article/view/32135/145 $\underline{28}$

Arivina, A. N., \& Jailani, J. (2020). Development of trigonometry learning kit with a STEM approach to improve problem solving skills and learning achievement. Jurnal Riset Pendidikan Matematika, 7(2). Diunduh dari https://journal.uny.ac.id/index.php/jrpm/article/view/35063/15003

Artigue, M. (2012). Challenges in basic mathematics education. Paris. Francia: UNESCO. Recuperado de Http://Unesdoc. Unesco. Org/Images/0019/001917/191776e. Pdf. Diunduh dari https://www.academia.edu/4166750/CHALLENGES_IN_BASIC_ MATHEMATICS_EDUCATION_UNESCO

Association, N. E. (2012). Preparing 21st century students for a global society: An educator's guide to the "Four Cs." Alexandria, VA: National Education Association. Diunduh dari https://www.academia.edu/36311252/Preparing_21st_Century_Stu dents_for_a_Global_Society_An_Educators_Guide_to_the_Four_Cs_ Great_Public_Schools_for_Every_Student

Astutik, H. S. (2017). Keefektifan pembelajaran berdasarkan masalah pada bangun ruang sisi datar ditinjau dari penguasaan SK, motivasi, dan minat siswa SMP. Jurnal Riset Pendidikan Matematika, 4(1), 56. https://doi.org/10.21831/jrpm.v4i1.12722. Diunduh dari https://journal.uny.ac.id/index.php/jrpm/article/view/12722/9432

Atsnan, F., Pabowo, B., \& Muzaki, A. (2018). Pengaruh pendekatan problem solving terhadap kemampuan representasi dan literasi matematis siswa The effect of problem solving approach toward 
students ' mathematical representation and literacy skill. Jurnal Riset Pendidikan Matematika, 5(2), 135-146. Diunduh dari https://journal.uny.ac.id/index.php/jrpm/article/view/20120/1169 $\underline{2}$

Conway, P. F., \& Sloane, F. C. (2005). International Trends in Post-Primary Mathematics Education: Perspectives on Learning, Teaching and Assessment. Science, 5, 4-10. http://www.ncca.ie/uploadedfiles/Publications/MathsResearch.pdf . Diunduh dari https://ulir.ul.ie/bitstream/handle/10344/5002/Conway_2005_repo rt.pdf?sequence $=2$

Farib, P. M., Ikhsan, M., \& Subianto, M. (2019). Proses berpikir kritis matematis siswa sekolah menengah pertama melalui discovery learning. Jurnal Riset Pendidikan Matematika, 6(1), 99-117. Diunduh dari

https://journal.uny.ac.id/index.php/jrpm/article/view/21396/127 $\underline{10}$

Fatmasuci, F. W. (2017). Pengembangan perangkat pembelajaran berbasis masalah berorientasi pada kemampuan komunikasi dan prestasi belajar matematika siswa SMP. Jurnal Riset Pendidikan Matematika, 4(1), 32. https://doi.org/10.21831/jrpm.v4i1.11325. Diunduh dari https://journal.uny.ac.id/index.php/jrpm/article/view/11325/9430

Habsah, F. (2017). Developing teaching material based on realistic mathematics andoriented to the mathematical reasoning and mathematical communication. Jurnal Riset Pendidikan Matematika, 4(1), 43-55. Diunduh dari https://journal.uny.ac.id/index.php/jrpm/article/view/10199/943 $\underline{1}$

Hadiat, H. L., \& Karyati, K. (2019). Hubungan kemampuan koneksi matematika, rasa ingin tahu dan self-efficacy dengan kemampuan penalaran matematika. Jurnal Riset Pendidikan Matematika, 6(2), 200210. https://doi.org/10.21831/jrpm.v6i2.26552. Diunduh dari https://journal.uny.ac.id/index.php/jrpm/article/view/26552/1341 $\underline{0}$

Hamidy, A., \& Jailani, J. (2019). Kemampuan proses matematis siswa Kalimantan Timur dalam menyelesaikan soal matematika model PISA. Jurnal Riset Pendidikan Matematika, 6(2), 133-149. Diunduh dari https://journal.uny.ac.id/index.php/jrpm/article/view/26679/131 $\underline{50}$

Hardiyanto, W., \& Santoso, R. H. (2018). Efektivitas PBL setting TTW dan TPS ditinjau dari prestasi belajar, berpikir kritis dan self-efficacy siswa. Jurnal Riset Pendidikan Matematika, 5(1), 116. https://doi.org/10.21831/jrpm.v5i1.11127. Diunduh dari https://journal.uny.ac.id/index.php/jrpm/article/view/11127/109 $\underline{40}$

Hariyanti, F., \& Wutsqa, D. U. (2020). Pengembangan perangkat 
pembelajaran statistika dan peluang untuk mengembangkan statistical literacy siswa SMP. Jurnal Riset Pendidikan Matematika, 7(1), 46-58. Diunduh dari https://journal.uny.ac.id/index.php/jrpm/article/view/14997/1435 $\underline{7}$

Jailani, J., Sugiman, S., \& Apino, E. (2017). Implementing the problembased learning in order to improve the students' HOTS and characters. Jurnal Riset Pendidikan Matematika, 4(2), 247-259. Diunduh dari

https://journal.uny.ac.id/index.php/irpm/article/view/17674/1019 $\underline{4}$

Johar, R., \& Lubis, K. R. (2018). The analysis of students' mathematical representation errors in solving word problem related to graph. Jurnal Riset Pendidikan Matematika, 5(1), 96. https://doi.org/10.21831/jrpm.v5i1.17277. Diunduh dari https://journal.uny.ac.id/index.php/irpm/article/view/17277/1112 $\underline{4}$

Kartianom, K., \& Ndayizeye, O. (2017). What 's wrong with the Asian and African Students' mathematics learning achievement? The multilevel PISA 2015 data analysis for Indonesia, Japan, and Algeria. Jurnal Riset Pendidikan Matematika, 200. https://doi.org/10.21831/jrpm.v4i2.16931. Diunduh dari https://journal.uny.ac.id/index.php/jrpm/article/view/16931/1018 $\underline{9}$

Kurniyawati, Y., Mahmudi, A., \& Wahyuningrum, E. (2019). Efektivitas problem-based learning ditinjau dari keterampilan pemecahan masalah dan kemandirian belajar matematis. Jurnal Riset Pendidikan Matematika, 6(1), 118-129. Diunduh dari https://journal.uny.ac.id/index.php/jrpm/article/view/26985/12711

Latifah, U. H., \& Widjajanti, D. B. (2017). Pengembangan bahan ajar statistika dan peluang berbasis multiple intelligences berorientasi pada prestasi, pemecahan masalah, dan rasa ingin tahu. Jurnal Riset $\begin{array}{rrr}\text { Pendidikan Matematika, } & \text { 4(2), }\end{array}$ https://doi.org/10.21831/jrpm.v4i2.13083. Diunduh dari https://journal.uny.ac.id/index.php/jrpm/article/view/13083/1018 $\underline{7}$

Lutfi, A. (2019). Pengembangan perangkat pembelajaran menggunakan problem solving dalam problem posing berbasis pendekatan saintifik. Jurnal Riset Pendidikan Matematika, 6(1), 27-38. https://doi.org/10.21831/jrpm.v6i1.10231. Diunduh dari https://journal.uny.ac.id/index.php/irpm/article/view/10231/1253 $\underline{5}$

Martin, W. G. (2000). Principles and standards for school mathematics (Vol. 1). National Council of Teachers of. Diunduh dari https://citeseerx.ist.psu.edu/viewdoc/download?doi=10.1.1.911.856 $\underline{1 \& \text { rep }=\text { rep } 1 \& \text { type }=p d f}$ 
Miatun, A., \& Nurafni, N. (2019). Profil kemampuan berpikir kreatif matematis ditinjau dari gaya kognitif reflective dan impulsive. Jurnal Riset Pendidikan Matematika, 6(2), 150-164. https://doi.org/10.21831/jrpm.v6i2.26094. Diunduh dari https://journal.uny.ac.id/index.php/jrpm/article/view/26094/1340 $\underline{6}$

Murtiyasa, B. (2016). Isuee. Prosiding Konferensi Nasional Penelitian Matematika Dan Pembelajarannya, Knpmp I, 1-10. Diunduh dari https://publikasiilmiah.ums.ac.id/bitstream/handle/11617/7051/0 _Makalah\%20REVISI\%20_Pak\%20Budi.pdf;sequence=1

Narendrati, N. (2017). Komparasi pembelajaran statistika melalui pendekatan CTL dan problem posing ditinjau dari prestasi belajar dan minat belajar matematika. Jurnal Riset Pendidikan Matematika, 4(1), 67. https://doi.org/10.21831/jrpm.v4i1.12723. Diunduh dari https://journal.uny.ac.id/index.php/jrpm/article/view/12723/9444

Noer, S. H. (2018). Guided discovery model: An alternative to enhance students' critical thinking skills and critical thinking dispositions. Jurnal Riset Pendidikan Matematika, 5(1), 108. https://doi.org/10.21831/jrpm.v5i1.16809. Diunduh dari https://journal.uny.ac.id/index.php/jrpm/article/view/16809/1112 $\underline{0}$

Novita, R., Charitas, R., Prahmana, I., Fajri, N., \& Putra, M. (2018). Penyebab kesulitan belajar geometri dimensi tiga The cause of difficulty in learning the three-dimensional geometry. 5(1), 18-29. Diunduh dari https://journal.uny.ac.id/index.php/jrpm/article/view/16836/107 $\underline{94}$

Nugroho, D. A. (2019). Pengembangan perangkat pembelajaran geometri dengan mengadaptasi model CORE untuk meningkatkan efikasi diri. Jurnal Riset Pendidikan Matematika, 6(1), 39-52. https://doi.org/10.21831/jrpm.v6i1.11599. Diunduh dari https://journal.uny.ac.id/index.php/jrpm/article/view/11599/1267 $\underline{7}$

Nurdin, E., Ma'aruf, A., Amir, Z., Risnawati, R., Noviarni, N., \& Azmi, M. P. (2019). Pemanfaatan video pembelajaran berbasis Geogebra untuk meningkatkan kemampuan pemahaman konsep matematis siswa SMK. Jurnal Riset Pendidikan Matematika, 6(1), 87-98. https://doi.org/10.21831/jrpm.v6i1.18421. Diunduh dari https://journal.uny.ac.id/index.php/jrpm/article/view/18421/127 $\underline{09}$

Nursyahidah, F., \& Albab, I. U. (2017). Investigating student difficulties on integral calculus based on critical thinking aspects. Jurnal Riset Pendidikan Matematika, 4(2), 211. https://doi.org/10.21831/jrpm.v4i2.15507. Diunduh dari https://journal.uny.ac.id/index.php/jrpm/article/view/15507/1019 $\underline{0}$

Purnomo, M. E. R., Sari, C. K., Rejeki, S., \& Machromah, I. U. (2018). 
Efikasi diri mahasiswa pada perkuliahan kalkulus integral. Jurnal Riset Pendidikan Matematika, 5(2), 181-189. https://doi.org/10.21831/jrpm.v0i0.20271. Diunduh dari https://journal.uny.ac.id/index.php/jrpm/article/view/20271/1188 $\underline{6}$

Purwasih, R., \& Bernad, M. (2018). Pembelajaran diskursus multi representasi terhadap peningkatan kemampuan komunikasi dan disposisi matematis mahasiswa Learning multi discourse representation to enhance students communication and their mathematical disposition. Jurnal Riset Pendidikan Matematika, 5(1), 43$52 . \quad$ Diunduh dari https://journal.uny.ac.id/index.php/jrpm/article/view/13589/111 $\underline{22}$

Safitri, W. Y., Retnawati, H., \& Rofiki, I. (2020). Pengembangan film animasi aritmetika sosial berbasis ekonomi syariah untuk meningkatkan minat belajar siswa MTs. 7(2), 195-209. Diunduh dari https://journal.uny.ac.id/index.php/jrpm/article/view/34581/150 $\underline{16}$

Salim, S., \& Maryanti, E. (2017). Pengembangan perangkat pembelajaran matematika melalui teori pembelajaran sibernetik berbantuan software derive. Jurnal Riset Pendidikan Matematika, 4(2), 229. https://doi.org/10.21831/jrpm.v4i2.16068. Diunduh dari https://journal.uny.ac.id/index.php/irpm/article/view/16068/1019 $\underline{2}$

Samo, D. D. (2017). Kemampuan pemecahan masalah matematika mahasiswa tahun pertama dalam memecahkan masalah geometri konteks budaya. Jurnal Riset Pendidikan Matematika, 4(2), 141. https://doi.org/10.21831/jrpm.v4i2.13470. Diunduh dari https://journal.uny.ac.id/index.php/irpm/article/view/13470/1018 $\underline{4}$

Sari, R. H. N., \& Wijaya, A. (2017). Mathematical literacy of senior high school students in Yogyakarta. Jurnal Riset Pendidikan Matematika, 4(1), 100. https://doi.org/10.21831/jrpm.v4i1.10649. Diunduh dari https://journal.uny.ac.id/index.php/jrpm/article/view/10649/9450

Sariningsih, R., \& Herdiman, I. (2017). Mengembangkan kemampuan penalaran statistik dan berpikir kreatif matematis mahasiswa di Kota Cimahi melalui pendekatan open-ended. Jurnal Riset Pendidikan Matematika, 4(2), 239. https://doi.org/10.21831/jrpm.v4i2.16685. Diunduh dari https://journal.uny.ac.id/index.php/irpm/article/view/16685/1019 $\underline{3}$

Satrianawati, S. (2017). Pengembangan materi bangun ruang sisi datar sebagai bagian dari persiapan calon guru sekolah dasar. Jurnal Riset $\begin{array}{rrr}\text { Pendidikan Matematika, } & \text { 4(1), }\end{array}$ https://doi.org/10.21831/jrpm.v4i1.11469. Diunduh dari https://journal.uny.ac.id/index.php/irpm/article/view/11469/9451 
Satriawan, R. (2017). Keefektifan Model Search, Solve , Create , and Share Ditinjau dari Prestasi , Penalaran Matematis, dan Motivasi Belajar The Effectiveness of the Model of Search, Solve, Create, and Share Terms of Achievement, Mathematical Reasoning, and Motivation. Jurnal Riset Pendidikan Matematika, 4(1), 87-99. Diunduh dari https://journal.uny.ac.id/index.php/jrpm/article/view/7863/9449

Setiana, D. S., \& Purwoko, R. Y. (2020). Analisis kemampuan berpikir kritis ditinjau dari gaya belajar matematika siswa. Jurnal Riset Pendidikan Matematika, 7(2), 163-177. Diunduh dari https://journal.uny.ac.id/index.php/jrpm/article/view/34290/1499 $\underline{5}$

Setiawan, Y. B., Hapizah, H., \& Hiltrimartin, C. (2018). Kesalahan siswa dalam menyelesaikan soal Olimpiade SMP konten aljabar Students ' error in solving junior high school Olympiad problem on algebra content. Jurnal Riset Pendidikan Matematika, 5(2), 3. Diunduh dari https://journal.uny.ac.id/index.php/jrpm/article/view/18191/119 $\underline{07}$

Stephan, M. L., Fish, M. C., Chval, K. B., Herbel-Eisenmann, B., Wanko, J. J., Konoid, C., Civil, M., \& Wilkerson, T. L. (2015). Grand challenges and opportunities in mathematics education research. Journal for Research in Mathematics Education, 46(2), 134-146. https://doi.org/10.5951/jresematheduc.46.2.0134. Diunduh dari https://www.nctm.org/Publications/journal-for-research-in-mathematicseducation/2015/Vol46/Issue2/Grand-Challenges-and-Opportunities-inMathematics-Education-Research/

Susanti, U., \& Wutsqa, D. U. (2020). Keefektifan pendekatan contextual teaching learning dan problem solving ditinjau dari prestasi dan kepercayaan diri siswa. 7(1), 97-107. Diunduh dari https://journal.uny.ac.id/index.php/jrpm/article/view/8537/14605

UNESCO. (2014). UNESCO education strategy 2014-2021. Author Paris. Diunduh dari http:// www.natcom.gov.jo/sites/default/files/231288e.pdf

UNESCO. (2015). Education 2030 Incheon Declaration and Framework for Action. World Education Forum 2015. Diunduh dari http://uis.unesco.org/sites/default/files/documents/education2030-incheon-framework-for-action-implementation-of-sdg4-2016en_2.pdf

Utami, R. W., \& Wutsqa, D. U. (2017). Analisis kemampuan pemecahan masalah matematika dan self-efficacy siswa SMP negeri di Kabupaten Ciamis. Jurnal Riset Pendidikan Matematika, 4(2), 166. https://doi.org/10.21831/jrpm.v4i2.14897. Diunduh dari https://journal.uny.ac.id/index.php/jrpm/article/view/14897/101 $\underline{86}$

Wahyuningrum, A. S., \& Latifah, T. (2020). Investigating mathematical conversation in remote learning of mathematics during the covid-19 pandemic. 7(2), 148-162. Diunduh dari 
https://journal.uny.ac.id/index.php/jrpm/article/view/34841/149 $\underline{93}$

Wasida, M. R., \& Hartono, H. (2018). Analisis kesulitan menyelesaikan soal model ujian nasional matematika dan self-efficacy siswa SMA. Jurnal Riset Pendidikan Matematika, 5(1), 82. https://doi.org/10.21831/jrpm.v5i1.10060. Diunduh dari https://journal.uny.ac.id/index.php/irpm/article/view/10060/1094 $\underline{1}$

Wibowo, A. (2017). Pengaruh pendekatan pembelajaran matematika realistik dan saintifik terhadap prestasi belajar, kemampuan penalaran matematis dan minat belajar. Jurnal Riset Pendidikan Matematika, 4(1), 1. https://doi.org/10.21831/jrpm.v4i1.10066. Diunduh https://journal.uny.ac.id/index.php/jrpm/article/view/10066/942 $\underline{7}$ 